\title{
ALBITIZATION IN THE INKISI SANDSTONES, REPUBLIC OF CONGO: CHARACTERIZATION AND INTERPRETATION
}

\author{
JEAN-DIDIER SOUNGA, PASCAL AFFATON, YVES NOACK AND FIDĖLE MIALOUNDAMA
}

\begin{abstract}
Albitization appears to be one of the most important transformations affecting aluminium silicates in the superficial zone of the Earth's crust, occurring in a variety of different formations. However, this process has not yet been clearly recognized in Africa. In this paper, we present the process of albitization in the context of an African sedimentary basin, in particular the Neoproterozoic to Palaeozoic arkosic sandstones of the Niari basin in the Republic of Congo. Differents faciès, mineral parageneses associated, chemical compositions of these albitizations are presented. The morphology of these albitization textures, which are often developed as a peripheral halo composed of pure albite surrounding (with a sharp contact) the practically unaltered potassium feldspar, would argue in favour of in situ albitization. In the same way, the presence of calcium-rich zones sometimes surrounding the albitized domains would support this hypothesis, the calcium being exsolved at the outer grain boundary during in situ formation of the albite. Thus, the presence of in situ albitization in the Inkisi sandstone could indicate an important marine influence on the sedimentary environment and diagenesis of these sandstones.
\end{abstract}

KEY WORDS: Albitization, Sandstone, Inkisi, Congo, Feldspar

\section{INTRODUCTION AND GENERAL REVIEW ABOUT ALBITIZATION}

The term "albitization" designates the process by which albite replaces certain minerals or is formed as a secondary phase in the pores of a rock. In a restrictive sense, this term refers to the transformation of plagioclase feldspars (anorthite-albite solid solution) and especially potassium feldspars (orthoclase, microcline) to albite (Smith, 1972, 1974; Moody et al., 1985; Slaby, 1992; Pérez et al., 2005).

Since the beginning of the $20^{\text {th }}$ century, albitization has been recognized as a process that mainly affects plagioclases in igneous basic rocks. One of the oldest publications on the subject is by Bailey and Grabham, (1909). Albitization was later identified as occurring in plagioclases of other igneous and metamorphic rocks, particularly in granites and granodiorites (Hess, 1950; Deer et al., 1963; Fox 1989), in alkali carbonatite complexes (Bodart 1980), in spilitized lavas (Eskola and al., 1935; Rosenbauer and al., 1988) and in volcanic tuffs (Boles and Coombs 1977).

Apart from plagioclases, some albitization has also been also observed in potassium feldspars of deepseated igneous rocks (Anderson, 1928; Anderson, 1937; Gilluly, 1933; Starkey, 1959; Smith 1974; Fox 1989).

Because of these early studies, research on albitization became essentially focused on rocks formed under high temperatures and pressures.
Although Tester and Atwater (1934) were the first to report the presence of authigenic feldspars in sediments, it is only recently that albitization processes have been recognized in sedimentary basins. These processes have been studied in the context of research on sandstones making up oilfield reservoirs, since albitization is able to modify the physical and chemical properties of reservoir rocks. Thus, the albitization of potassium feldspars has been described in the Jurassic, Lower Cretaceous and Tertiary reservoir sandstones of Norway (Saigal et al., 1988; Aagaard et al., 1990), in the Proterozoic arkoses and greywackes of Sweden (Morad, 1986), in Palaeozoic arkoses (Carboniferous called Pennsylvanian) in the region of Denver in Colorado (Walker, 1984) and in the sandstones of Quebec in Canada (Ogunyomi et al., 1981).

A certain number of oil exploration studies have also investigated the albitization of plagioclase in sedimentary rocks, as in the case of the Frio formations in Texas (Land and Milliken, 1981), the Steven sandstones in California (Boles, 1982 and 1984), the Miocene sandstones of Louisiana (Gold, 1987) and the Triassic sandstone reservoirs of the Snorre oilfield in the North Sea off Norway (Morad et al., 1990).

More studies have been carried out on albitized alteration in relation to uranium concentrations in France (Schmitt, 1983, 1986; Simon-Coinçon 1989). These authors have demonstrated the importance of albitization in controlling the redistribution and

Jean-Didier Sounga, Faculty of Sciences, Marien Ngouabi University, PO Box 69, Brazzaville, Congo Pascal Affaton, Aix-Marseille University, CNRS, CEREGE UM34, 13545 Aix en Provence cedex 4, France Yves Noack, Aix-Marseille University, CNRS, CEREGE UM34, 13545 Aix en Provence cedex 4, France Fidèle Mialoundama, Faculty of Sciences, Marien Ngouabi University, PO Box 69, Brazzaville, Congo 
concentration of metals in ore deposits $(\mathrm{U}, \mathrm{V}, \mathrm{Th}, \mathrm{Zr}, \mathrm{Y}$, $\mathrm{Sc}, \mathrm{Zn}, \mathrm{Ba}, \mathrm{Mn}$. and $\mathrm{Fe}$ ), particularly in the case of uranium. According to these studies, albitization plays an important role in controlling the location of uranium deposits in the Rouergue massif of France.

\section{STATEMENT OF PROBLEM}

In view of all these studies, albitization appears to be one of the most important transformations affecting aluminium silicates in the superficial zone of the Earth's crust, occurring in a variety of different formations.

However, this process has not yet been clearly recognized in Africa. Albitization appears to have been observed in Mali by $A$. Blot, as well as in the region of Bobo Dioulasso in Burkina Faso by G. Grandin, notably in the unconformity zone where Upper Proterozoic red sandstone overlies the basement (Blot and Grandin: oral communications). However, no scientific report on this subject has ever been published in the case of West Africa.

The aim of the present study is to present the process of albitization in the context of an African sedimentary basin, in particular the Neoproterozoic to Palaeozoic arkosic sandstones of the Niari basin in the Republic of Congo.

\section{MATERIALS AND METHODS}

The approach used in this study is essentially descriptive, based on a petrographic study using the optical microscope, supplemented by some observations and elemental microanalyses by scanning electron microscope (SEM). The optical polarizing microscope was a Leica DM RXP instrument, coupled to a Nikon Coolpix E 4500 digital camera. The observations and optical microphotography were carried out at the "European Centre of Research and Teaching in Environmental Geosciences (CEREGE) of Aix-enProvence. The scanning electron microscope (SEM) observations and microprobe analyses were performed at the Pluridisciplinary Centre of Electronic Microscopy and Microanalysis (CP2M), Faculty of Sciences of Saint Jérôme, University of Marseille (France).

Such an approach allowed us to make well founded mineralogical determinations and, especially, to establish the spatial and hierarchical relationships between the different minerals observed.

\section{GEOGRAPHICAL LOCATION AND GEOLOGICAL SETTING OF THE INKISI FORMATION}

The term "Inkisi Formation" is derived from the name of a tributary of the Congo River, situated in the northern part of the Democratic Republic of Congo (Central Africa), where this formation was first described (Cahen, 1954). Subsequently, the Inkisi Formation was recognized in the Republic of Congo (Cosson, 1955; Dadet 1969) and Angola (Stanton et al., 1963). On the other hand, it has not been yet observed in the Republic of Gabon.

Thus, on the scale of West Africa, the Inkisi Formation extends from the southern part of the Democratic Republic of Congo (DRC), across CongoBrazzaville and into the north of the Republic of Angola (Fig. 1). 


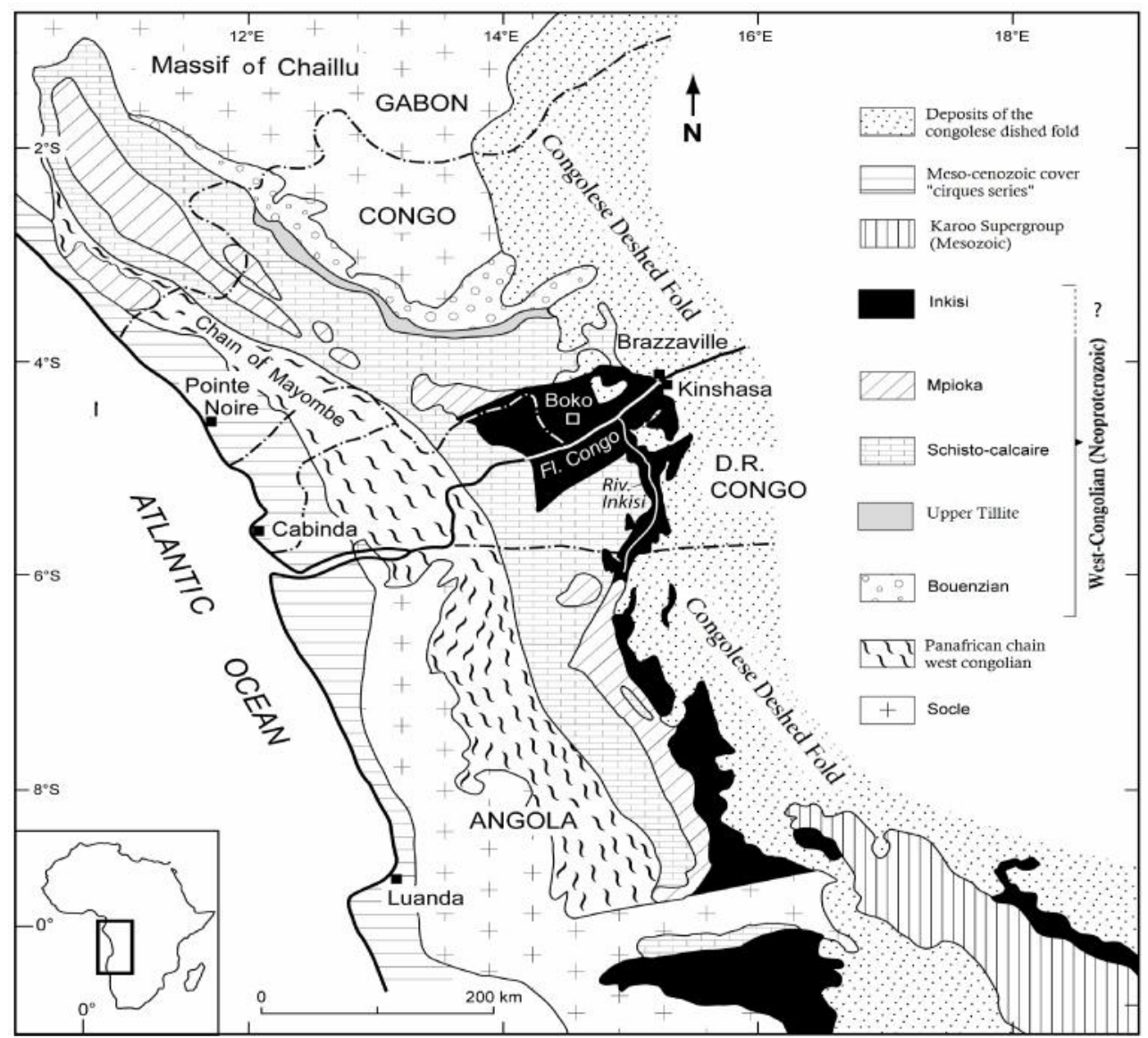

Fig. 1: Geographical location and geological setting of the Inkisi Formation [map built from the maps of Alvarez and al., (1995) and Frimmel and al., (2006)].

In the Republic of Congo (Congo-Brazzavile), where the present study was carried out, the Inkisi Formation crops out extensively to the west of Brazzaville, covering an area located between latitudes $4^{\circ}$ to $10^{\circ}$ South and longitudes $14^{\circ}$ to $20^{\circ}$ West.

From the stratigraphic point of view, the Inkisi Formation is the uppermost unit of an Upper Proterozoic geological succession named the "West-Congolian
System" as defined by Cosson (1955), in which the Inkisi Formation is described as a Series.

The position of the Inkisi Formation at the top of the West-Congolian System has been also recognized by other authors (Tabl. 1), who describe this unit as forming a series, subseries or group in the Republic of Congo (Dadet, 1969; Boudzoumou 1986), in the Democratic Republic of Congo (Cahen, 1954) and in Angola (Stanton et al., 1963) as shown in Table 1. 
Table 1: Stratigraphic Position of the Inkisi Formation According to Different Authors

\begin{tabular}{|c|c|c|c|c|c|c|c|c|c|}
\hline \multirow{2}{*}{\multicolumn{2}{|c|}{$\begin{array}{c}\text { GABON } \\
\text { Dévigne (1959) }\end{array}$}} & \multicolumn{3}{|c|}{ CONGO } & \multicolumn{4}{|c|}{ D. R. CONGO } & \multirow{2}{*}{$\begin{array}{l}\text { ANGOLA } \\
\text { Stanton et al., } \\
(1963)\end{array}$} \\
\hline & & \multicolumn{2}{|c|}{$\begin{array}{l}\text { Cosson (1955) } \\
\text { Dadet (1969) }\end{array}$} & \multirow{2}{*}{$\begin{array}{l}\text { Boudzoumou } \\
\text { (1986); } \\
\text { Alvarez et } \\
\text { al., (1995) } \\
\text { Term and } \\
\text { Formation } \\
\text { of Inkisi }\end{array}$} & \multicolumn{2}{|c|}{$\begin{array}{l}\text { Cahen } \\
(1954,1978)\end{array}$} & \multicolumn{2}{|c|}{$\begin{array}{l}\text { Hartwig et al., } \\
(2006)\end{array}$} & \\
\hline \multirow{6}{*}{ 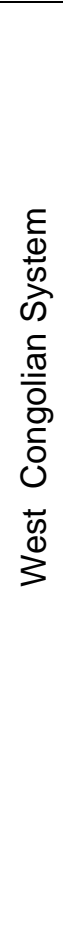 } & $\begin{array}{l}\text { Inkisi not } \\
\text { recognize } \\
\text { d }\end{array}$ & \multirow{6}{*}{ 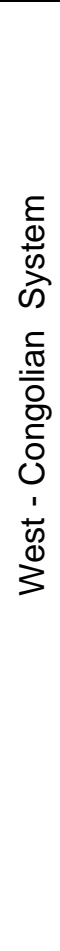 } & $\begin{array}{l}\text { Series of } \\
\text { l'Inkisi }\end{array}$ & & \multirow{6}{*}{ 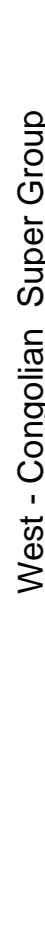 } & $\begin{array}{l}\text { Group of } \\
\text { l'Inkisi }\end{array}$ & \multirow{6}{*}{ 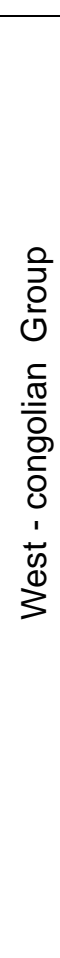 } & $\begin{array}{l}\text { Sub } \\
\text { Group of } \\
\text { Inkisi }\end{array}$ & $\begin{array}{l}\text { Sub } \\
\text { Series of } \\
\text { Inkisi }\end{array}$ \\
\hline & $\begin{array}{l}\text { Series of } \\
\text { Mpioka }\end{array}$ & & $\begin{array}{l}\text { Series of } \\
\text { Mpioka }\end{array}$ & $\begin{array}{l}\text { Formation } \\
\text { of Mpioka }\end{array}$ & & $\begin{array}{l}\text { Group of } \\
\text { Mpioka }\end{array}$ & & $\begin{array}{l}\text { Sub } \\
\text { Group of } \\
\text { Mpioka }\end{array}$ & $\begin{array}{l}\text { Sub } \\
\text { Series of } \\
\text { Mpioka }\end{array}$ \\
\hline & $\begin{array}{l}\text { Series of } \\
\text { Schisto- } \\
\text { calcaire }\end{array}$ & & $\begin{array}{l}\text { Series of } \\
\text { Schisto- } \\
\text { calcaire }\end{array}$ & $\begin{array}{l}\text { Group of } \\
\text { Schisto- } \\
\text { calcaire }\end{array}$ & & $\begin{array}{l}\text { Group of } \\
\text { Schisto- } \\
\text { calcaire }\end{array}$ & & $\begin{array}{l}\text { Sub } \\
\text { groupe of } \\
\text { Schisto- }\end{array}$ & \multirow{3}{*}{ 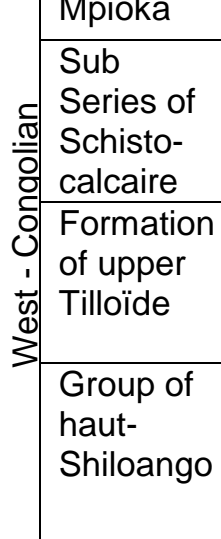 } \\
\hline & $\begin{array}{l}\text { Series of } \\
\text { upper } \\
\text { Tillite }\end{array}$ & & $\begin{array}{l}\text { Series of } \\
\text { upper Tillite }\end{array}$ & $\begin{array}{l}\text { Formation of } \\
\text { upper Tillite }\end{array}$ & & $\begin{array}{l}\text { Upper } \\
\text { Mixtite }\end{array}$ & & $\begin{array}{l}\text { Formation } \\
\text { of the } \\
\text { upper } \\
\text { Mixtite }\end{array}$ & \\
\hline & $\begin{array}{l}\text { Series of } \\
\text { Louila }\end{array}$ & & $\begin{array}{l}\text { Series of } \\
\text { Louila } \\
\text { (Bouenzian } \\
\text { ) }\end{array}$ & $\begin{array}{l}\text { Formation of } \\
\text { Louila } \\
\text { (Bouenzian) }\end{array}$ & & $\begin{array}{l}\text { Group of } \\
\text { Haut- } \\
\text { Shiloang } \\
\text { o }\end{array}$ & & $\begin{array}{l}\text { Sub } \\
\text { Groupe of } \\
\text { haut- } \\
\text { Shiloango }\end{array}$ & \\
\hline & $\begin{array}{l}\text { Series of } \\
\text { lower } \\
\text { Tillite }\end{array}$ & & $\begin{array}{l}\text { Series of } \\
\text { lower Tillite }\end{array}$ & $\begin{array}{l}\text { Formation of } \\
\text { lower Mixtite }\end{array}$ & & $\begin{array}{l}\text { Lower } \\
\text { Mixtite }\end{array}$ & & $\begin{array}{l}\text { Formation } \\
\text { of the } \\
\text { lower } \\
\text { Mixtite }\end{array}$ & $\begin{array}{l}\text { Formation } \\
\text { of lower } \\
\text { Tilloïde }\end{array}$ \\
\hline
\end{tabular}

Other authors consider that this formation has undergone a distinctly different history from the underlying succession, assigning it to the Palaeozoic (Alvarez et al., 1995) and arguing that this tabular formation appears to be unaffected by the Pan-African orogenesis that has deformed all the underlying formations. Moreover, in Angola, the Inkisi Formation is directly overlain by the Karoo deposits, which are of Permian age.

Owing to lack of precise dating results, the age of the Inkisi Formation is not yet clearly established, and could vary between the Upper Proterozoic and the Palaeozoic. The Inkisi Formation is of great interest to the oil industry due to its position on top of the Precambrian rocks of Congo, located at the transition with the fold belt of the Lower Congo Basin. Of the basis of field and petrographic observations, the Inkisi Formation exhibits two facies: a predominantly pink facies and a green facies. These two facies correspond to arkosic and subarkosic sandstones, according to the Q-F-Fr diagram of Folk (1974) (Fig 2) 


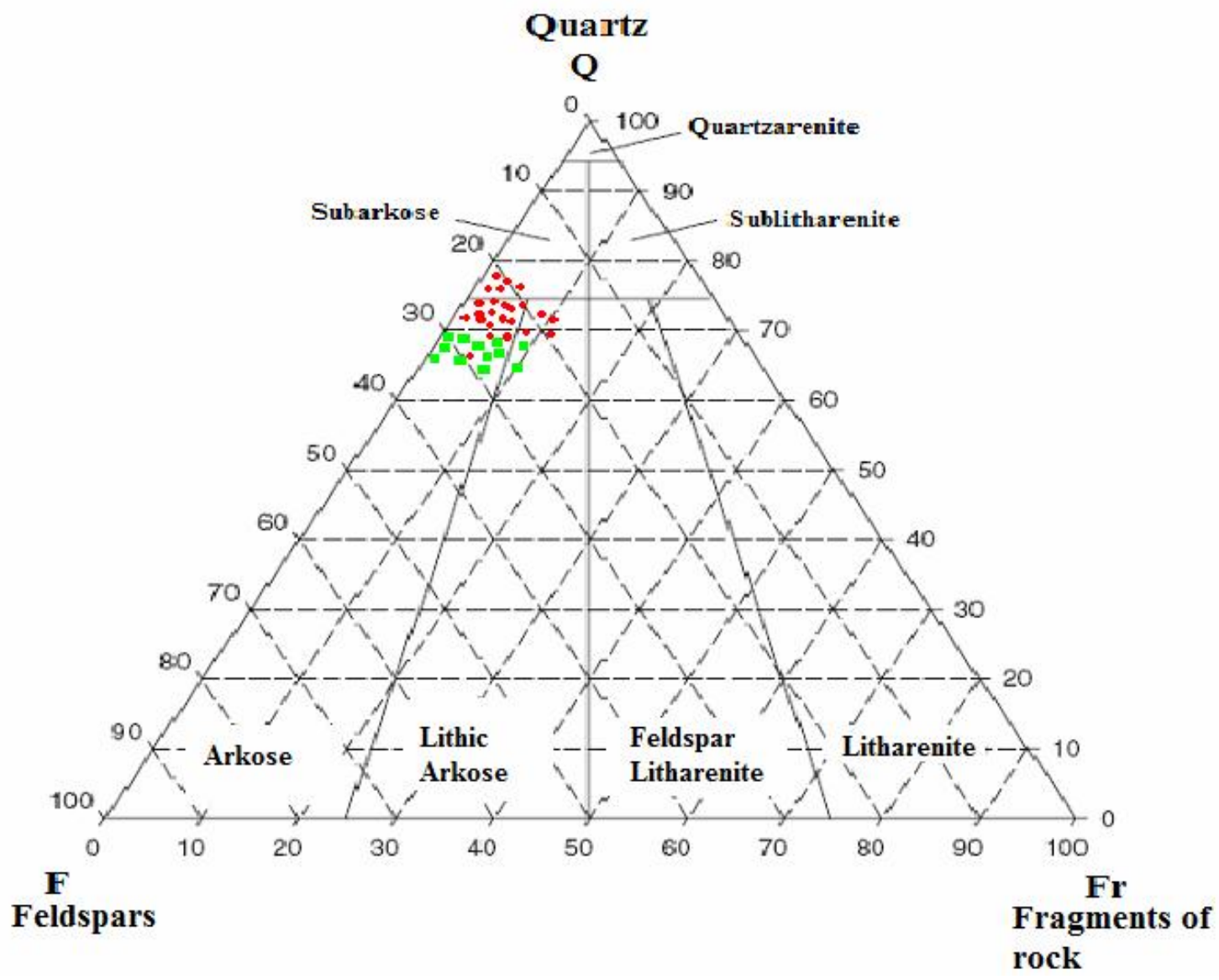

Fig. 2: Classification of the pink facies (circles) and green (squares) of the Inkisi sandstone in the diagram of Folk (1974).

The principal constituents of the sandstones are quartz (68 to $78 \%$ ), feldspar, essentially microcline (18 to $30 \%$ ), and lithoclasts commonly of quartzite (2 to $12 \%)$. Some flakes of micas, essentially muscovite (2 to $5 \%$ ) are also present. The cement is essentially ferruginous (hematite) and clayey (illite, smectite and chlorite). The general texture is grain-supported.

However, there are some substantial mineralogical differences between the two facies. Quartz is more abundant in the pink facies and feldspars are more common in the green facies. In terms of clay mineralogy, the pink facies are dominated by the smectite - illite and the green facies by chlorite - illite.

\section{ALBITIZATION FACIES}

The albitization facies observed under the optical microscope exhibit different forms and textures, the most characteristic texture being peripheral or perthitic, along with the development of twinning, as well as chessboard, channel and polar albitization (plate I).

\section{Peripheral albitization:}

This is present as a halo of albite around relatively unaltered crystals of potassium feldspar, mostly composed of microcline easily recognizable by its clear cross-hatched twinning pattern resembling a tartan (plate I, photo 1).

The halo is irregular and discontinuous, being absent at the contact points with the neighbouring grains. Its thickness is therefore variable and corresponds, at the most, to $1 / 5$ of the grain size. The halo is distinctly differentiated from the host feldspar since it is colourless in plane polarized light PPL (plate I, photo 2), showing clearer grey interference colours in cross-polarized light CPL (plate I, photo 1). The halo is finely dotted with brownish alteration products (clearly visible in PPL) concentrated close to the contact with the band of central feldspar, which impart the reddish colour already perceptible to the naked eye and especially under the magnifying glass. At higher magnification, next to these more high-birefringence globular alteration products, we observe abundant small minerals more or less elongate or in rods, which are of greenish colour and showing higher birefringence.

The boundary between the albitized halo and the non-albitized central part of the potassium feldspar appears fresh, sharp and linear. In a general manner, this boundary appears very smooth and regular, although sometimes it is curved and penetrates into the contacts of the unaltered part of the mineral. This feature is very striking.

Perthitic albitization: on the inner side of the peripheral fringe, albitization penetrates into the unaltered potassium feldspar, spreading along a regular network of cleavage planes. In this way, the albite grows in linear and parallel bands that form stripes crossing the potassium feldspar, as illustrated in photo 3 , plate $\mathbf{I}$.

These internal albitic bands have the same optical characters (colour, birefringence, angle of extinction) as the peripheral halo; the two types of albitization (peripheral and internal) are therefore 
developed in optical continuity, probably with the same crystallographic orientation. As already observed in the previous case, some brownish globular products also occur within the internal and peripheral domains of albitization.

\section{Albitization associated with polysynthetic twins or chessboard patterns:}

In some cases, the albitized bands show clearly perceptible polysynthetic twins in plane polarized light (PPL) (Photo 4, plate I). Observed under high magnification, this albitized band appears to be made up by the juxtaposition of $20-\mu \mathrm{m}$ sized grains in a chessboard pattern (Starkey 1959), oriented parallel to the polysynthetic twin of the microcline.

\section{Channel albitization:}

This type of albitization penetrates the whole grain, isolating some multiform relicts of the unaltered potassium feldspar (Plate I, photos 5 and 6). The process of albitization leads to the

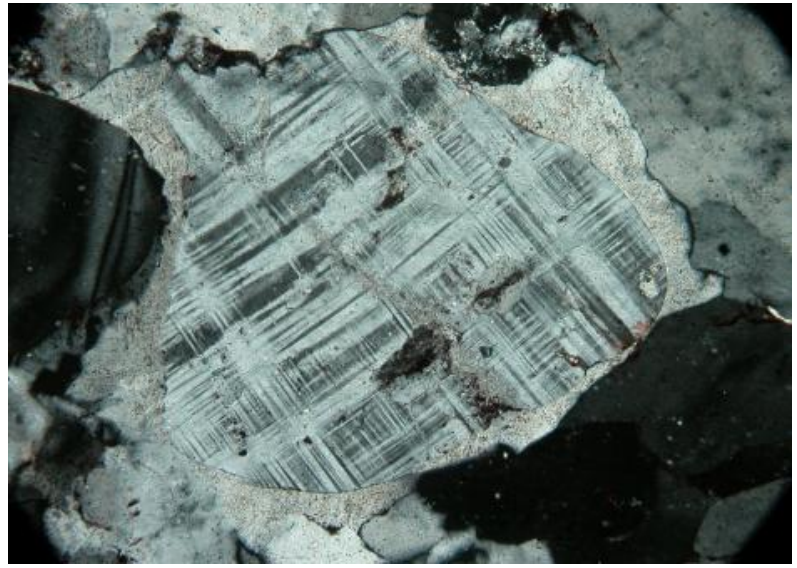

Photo 1: Aureole of albitizations of microcline CPL - Scale: $200 \mu$

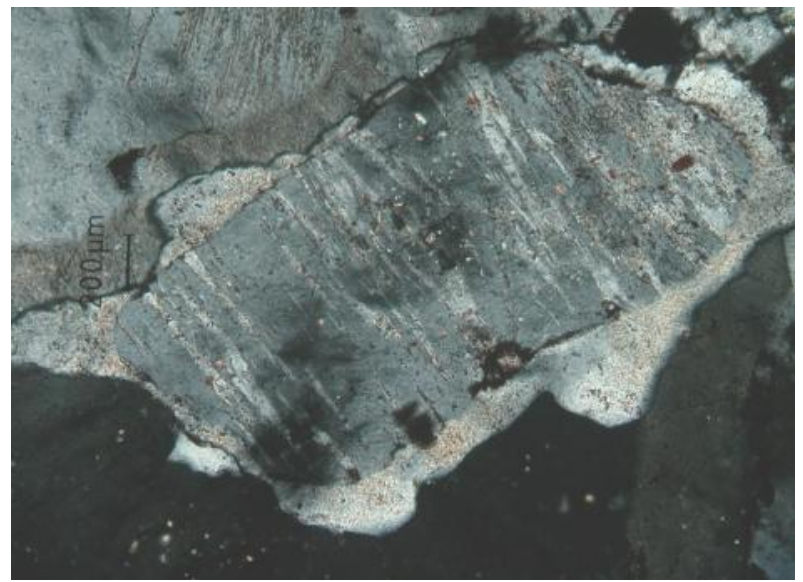

Photo 3: Perthitics albitizations CPL - Scale: $200 \mu \mathrm{m}$

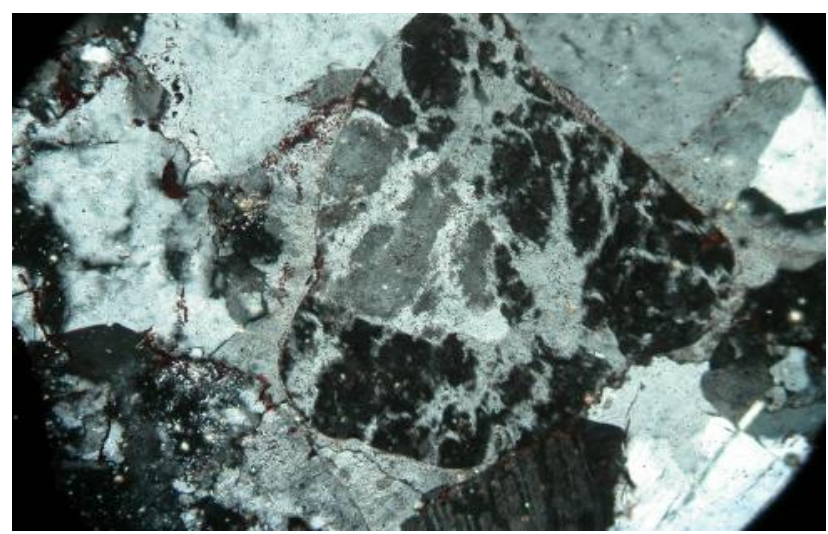

Photo 5 : Channel albitizations CPL - Scale: $200 \mu$

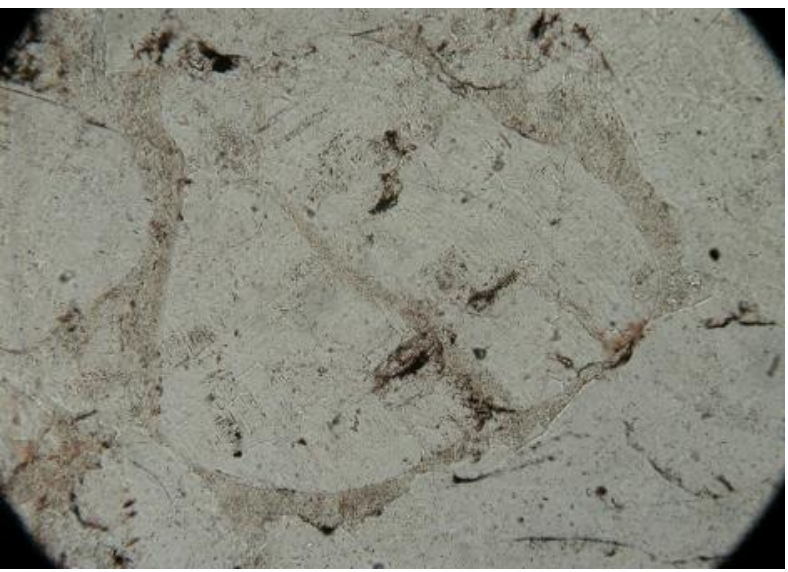

Photo 2: Same fringe than photo 1, in Plane Polarized light view PPL - Scale: $200 \mu$

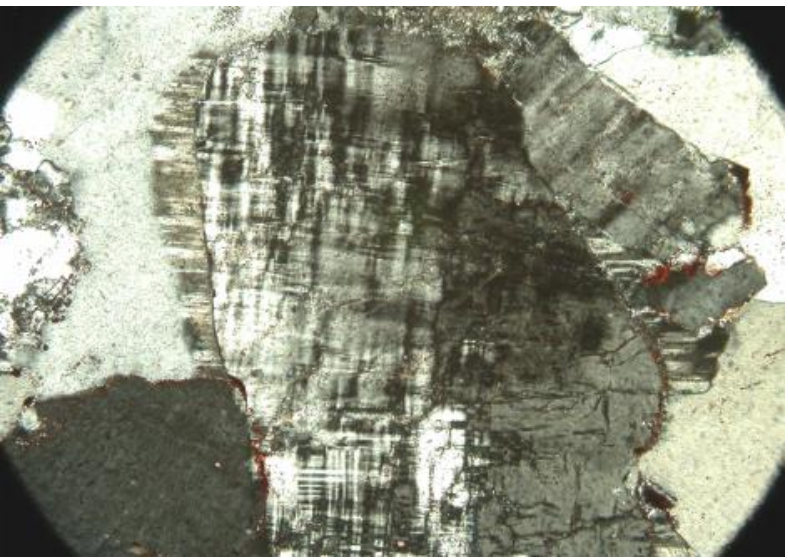

Photo 4: Albitizations in a chequered pattern or in a polysynthetic twin. CPL - $200 \mu m$

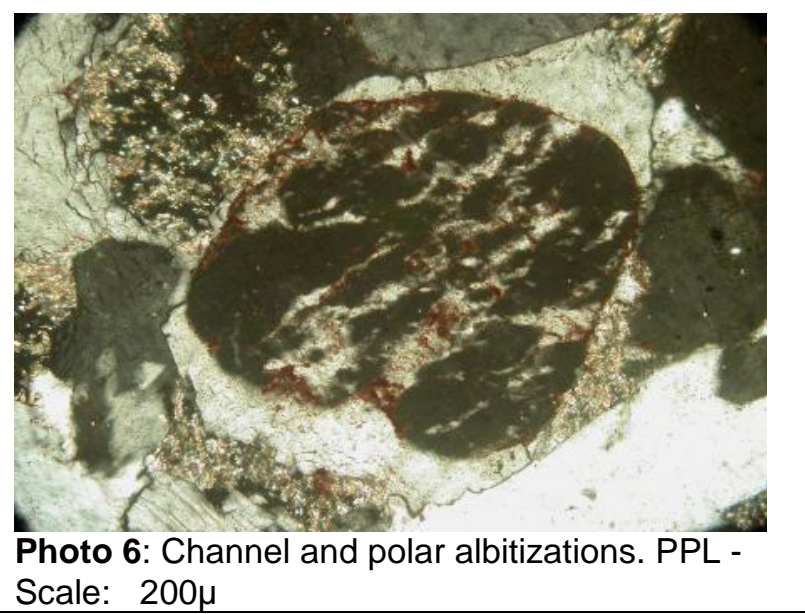

Plate I: Principal facies of albitization in the Inkisi Formation sandstone, observed under the optical microscope formation of large interconnected bands separating islets of relatively unaltered potassium feldspar. These islets are 
seen in high relief against the albitized background. We observe fibrous minerals close to the brown and yellow globular products, especially concentrated in the middle of the albitized bands (plate I, photo 6). The fibres of these minerals appear unidirectional, oriented in the same direction and perpendicularly to the outlines of the unaltered band.

\section{Polar albitization:}

In this case, the albitized bands are developed on the opposite sides of the apparently intact potassium feldspar, which is striped with anastomosing channels of albite. Such an arrangement seems to reflect a polarity in the development of the albitization (Plate I, photo 6).

\section{MINERAL PARAGENESES ASSOCIATED WITH ALBITIZATION}

Under the optical microscope, it is common to observe particular mineral parageneses associated with albitization.

\section{Albitization associated with quartz:}

The observed albitization is often associated with quartzification (Plate II, photo 1).

The overall reaction involving the direct albitization of potassium feldspar, as proposed by some authors (Walker, 1984; Saigal et al., 1988; Ben Baccar and al., 1993), can be written as follows:

$\left[\mathrm{Si}_{3} \mathrm{AlO}_{8}\right] \mathrm{K}+\mathrm{Na}^{+} \rightarrow\left[\mathrm{Si}_{3} \mathrm{AlO}_{8}\right] \mathrm{Na}+\mathrm{K}^{+}$

To express the release of silica to produce quartz, we propose to express this overall process by the following pair of reactions:

$4 \mathrm{KAISi}_{3} \mathrm{O}_{4}+2 \mathrm{Na}^{+}+8 \mathrm{H}_{2} \mathrm{O}=2 \mathrm{NaAlSi}_{3} \mathrm{O}_{8}+4 \mathrm{~K}^{+}+8 \mathrm{H}^{+}+2 \mathrm{Al}^{3+}+6 \mathrm{H}_{4} \mathrm{SiO}_{4}$

$\mathrm{H}_{4} \mathrm{SiO}_{4}=\mathrm{SiO}_{2}+2 \mathrm{H}_{2} \mathrm{O}$ 
Albitization associated with calcite

Some types of albitization are associated with calcite (Plate II, Photo 2). The calcium appears to be derived from the albitization of plagioclase, or potassium feldspar containing traces of calcium, according to the reaction: $\mathrm{NaAlSi}_{3} \mathrm{O}_{8} \cdot \mathrm{CaAl}_{2} \mathrm{Si}_{2} \mathrm{O}_{8}+\mathrm{H}_{4} \mathrm{SiO}_{4}+\mathrm{Na}^{+}=2 \mathrm{NaAlSi}_{3} \mathrm{O}_{8}+\mathrm{Al}^{3+}+\mathrm{Ca}^{2+}+4 \mathrm{OH}^{-}$

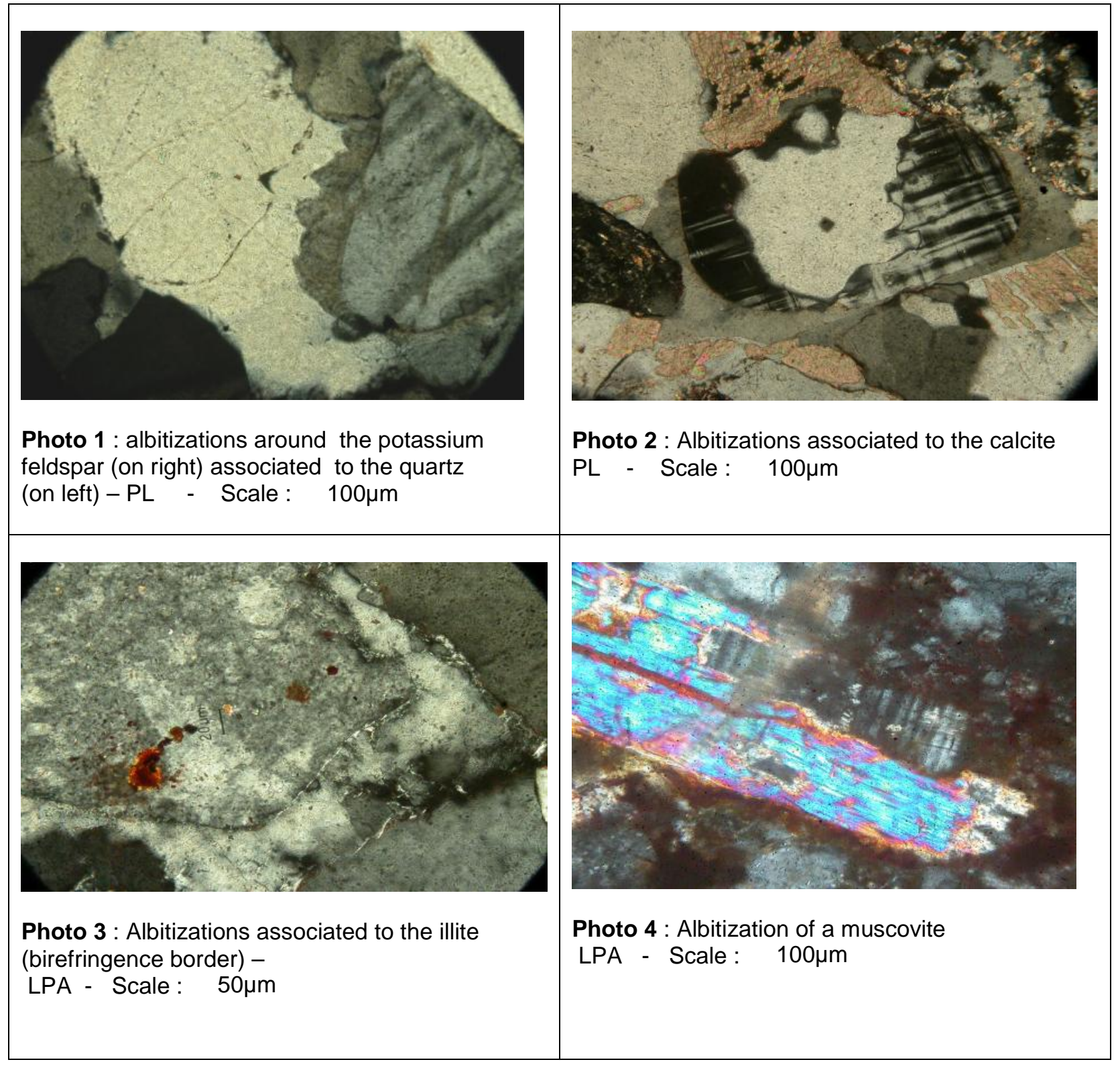

Plate II: Mineral parageneses associated with different types of albitization in the Inkisi sandstone.

\section{Albitization associated with phyllosilicate mineral (illite) \\ Some of the observed albitization is associated} with the formation of a phyllosilicate mineral (e.g. illite), making up some highly birefringence rims around the feldspar and the albitized band (Plate II, photo 3).

\section{Albitization affecting other minerals:}

In the Inkisi sandstone, albitization seems to affect other minerals apart from the feldspars. Thus, photo 4 of plate II shows feldspars with clearly visible polysynthetic twins, which appear to be growing at the expense of muscovite.

\section{CHEMICAL COMPOSITION OF ALBITIZED DOMAINS}

To determine the chemical composition of the albitized domains, we carried out microprobe analysis (Table 2) and established chemical distribution maps of the major elements (Plate. III) in the albitized potassium feldspar. 
Table 2: Chemical Composition of Albitized Domains and Host Potassium Feldspar, Obtained by Microprobe Analysis.

\begin{tabular}{|l|l|l|l|l|l|}
\hline & $\mathrm{Na}$ & $\mathrm{Al}$ & $\mathrm{Si}$ & $\mathrm{K}$ & $\mathrm{Ca}$ \\
\hline $\begin{array}{l}\text { Microanalysis 1: } \\
\text { peripheral albitization }\end{array}$ & 15.48 & 17.82 & 66.09 & 0.00 & 0.00 \\
\hline $\begin{array}{l}\text { Microalysis 2: Internal } \\
\text { vein albitization }\end{array}$ & 12.52 & 17.92 & 67.58 & 1.39 & 0.55 \\
\hline $\begin{array}{l}\text { Microanalysis 3: Internal } \\
\text { vein albitization }\end{array}$ & 14.39 & 18.89 & 64.89 & 1.28 & 0.53 \\
\hline $\begin{array}{l}\text { Microanalysis 4: } \\
\text { Potassim feldspar host }\end{array}$ & 0.85 & 16.76 & 61.88 & 19.77 & 0.00 \\
\hline
\end{tabular}

The microanalyses were performed on the clear albitized rims (microanalysis 1), on clear veins of internal albitization (microanalysis 2 and 3 ) and on the host potassium feldspars (microanalysis 4). The results are expressed as atomic proportions (Table 2).

These results show that the albitized domains, notably those at the rim, are composed of pure albite (containing only sodium, without calcium).

The elemental distribution maps confirm the exclusively sodic character of these albitized domains (Photos 2 and 3, plate III). The calcium is localized around the albitized band (Photo 4, plate III).

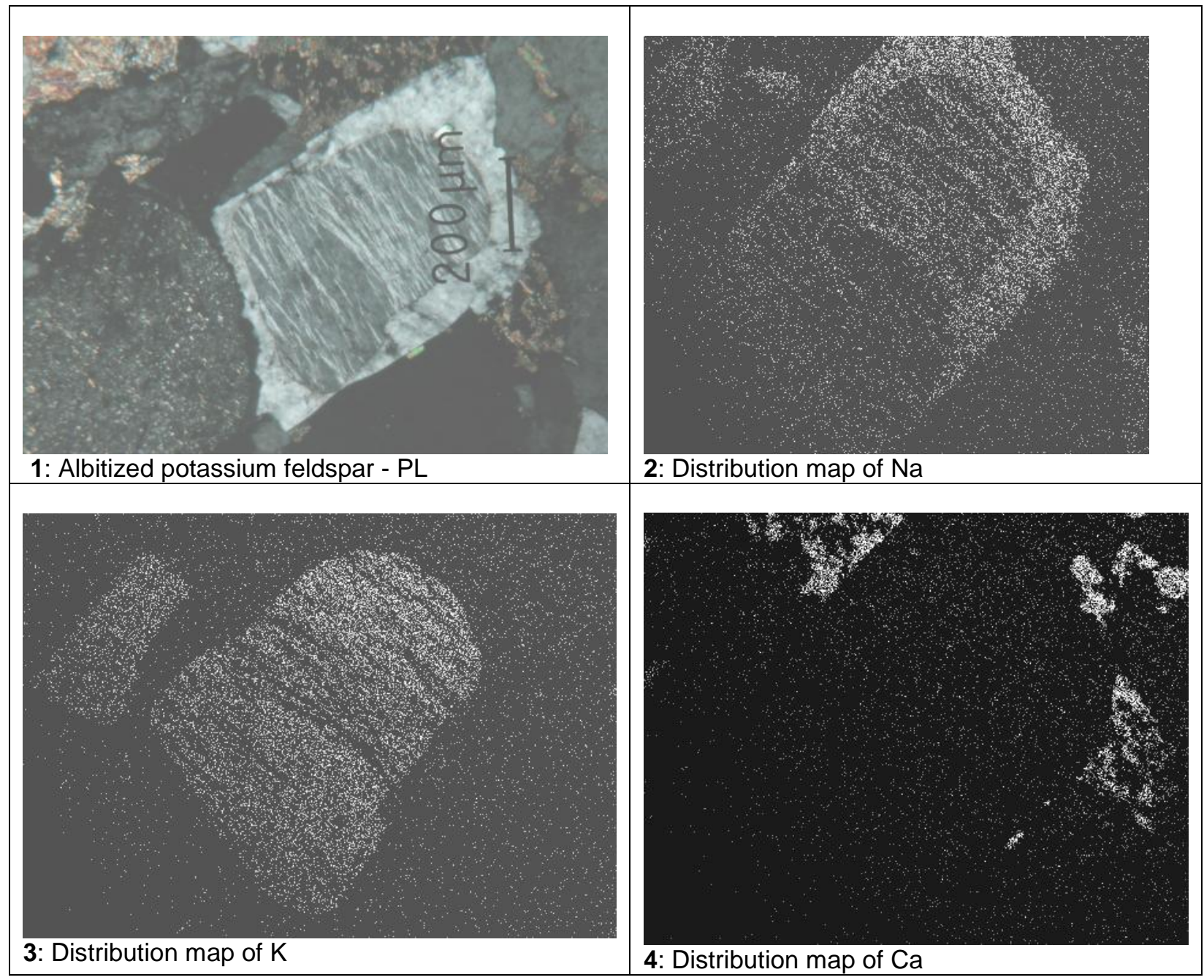

Plate III: Photo of potassium feldspar showing a fringe and albitized veins (1); distribution maps of sodium (2), potassium (3) and calcium (4) in the albitized potassium feldspar.

\section{DISCUSSION AND CONCLUSION}

As pointed out in the introduction, albitization is a process of transformation that affects the feldspars and possibly other minerals as well. This process has long been recognized in endogenous rocks, notably in igneous rocks containing potassium feldspars.

Albitization can be easily understood in the context of igneous or metamorphic rocks, because of the elevated pressures and temperatures that govern 
their formation (feldspars being minerals that are generally formed at high temperatures). On the other hand, there is still much controversy about the process of albitization in sedimentary rocks and alterites, which are formed at low pressures and very low temperatures.

This explains why two schools of thought have arisen. Some authors consider that certain types of albitization can occur in-situ in sedimentary rocks, by hydrothermal processes during diagenesis ( Ogunyomi et al., 1981; Walker, 1984; Morad 1986) and even at surface conditions during supergene alteration (Schmitt 1986), according to mechanisms that remain to be specified. In these cases, the albite is of lowtemperature type. On the other hand, other authors exclude the possibility of in situ formation of diagenetic or supergene low- temperature albite. These authors suggest a simple inheritance from the parent rock, in which the clastic material is already albitized before incorporation in the sediment. The albitization observed in sedimentary rocks, notably in sandstones, would therefore simply reflect inheritance from endogenous parent rocks (Ollerenshaw, 1967; Lajoie, 1973; Tawadros 1977).

This study describes the main albitization facies observed in sandstones from an African sedimentary context where these types of texture have been seldom reported. We lack sufficient data to determine whether the albitization is autochthonous (authigenic) or allochtonous (inheritance of detrital grains). However, the morphology of these albitization textures, which are often developed as a peripheral halo composed of pure albite surrounding (with a sharp contact) the practically unaltered potassium feldspar, would argue in favour of in situ albitization. In the same way, the presence of calcium-rich zones sometimes surrounding the albitized domains (Photo 4, plate III) would support this hypothesis, the calcium being exsolved at the outer grain boundary during in situ formation of the albite.

The albitization reaction requires a considerable input of sodium, which can then enter the crystal lattice by substituting for the potassium in the host mineral (in this case, microcline). Thus, the presence of in situ albitization in the Inkisi sandstone could indicate an important marine influence on the sedimentary environment and diagenesis of these sandstones. Previous authors evoked a purely continental origin for this formation, suggesting that it was deposited in fluvial channels (Cahen, 1954; Cosson, 1955; Dadet, 1969; Boudzoumou 1986). More recent studies assigned a deltaic origin to this formation (Alvarez and al., 1995), which is compatible with the interpretation given here, that is, that the Inkisi Formation was subjected to a strong marine influence during its deposition, which would have had some effects on the diagenesis of the sandstones.

To obtain a better knowledge of albitization phenomena in sedimentary rocks, it will be necessary to carry out a finer-resolution petrographic approach using the scanning electron microscope (SEM) and the microprobe. This would allow us to improve our understanding of the relationships between the different types of albitization and the mineral parageneses associated with them. In addition, some interesting results can be obtained using oxygen and hydrogen isotopes as tracers of the fluids in the context of diagenesis.

\section{REFERENCES}

AAGAARD, P., EGEBERG, P. K., SAIGAL, GC., MORAL, S., and BJORLYKKE, K., 1990. Diagenetic albitisation of detrital K-feldspars in Jurassic, Lower Cretaceous and Tertiary clastic reservoir rocks from offshore Norway, II. Formation water chemistry and kinetic considerations: Journal of Sedimentary Petrology, v. 60, p. 575-581.

ALVAREZ, P., MAURIN, J.-C., VICAT, J.-P., 1995, La formation de l'Inkisi (Supergroupe Ouestcongolien) en Afrique centrale (Congo et BasZaïre) : un delta d'age Paléozoïque comblant un bassin en extension. J. Afr. Earth Sci.20, 119131.

ANDERSON, O., 1928, The genesis of some types of feldspar from granite pegmatites: Norsk Geol. Tidsskr., v. 10, p. 116-208.

ANDERSON, G. H., 1937. granitization, albitization, and related phenomena in the northern Inyo Range of California-Nevada: Geol. Soc. Amer. Bull., v. 48 , p. 1-74.

BAILEY, E.B. and GRABHAM, G. W., 1909. Albitisation of basic plagioclase feldspars: Geological Magazine, v.6, p.250-256.

BEN BACCAR, M., FRITZ, B. and MADE, B., 1993. Diagenetic albitization of K-feldspar and plagioclase in sand stone reservoirs: Thermodynamic and kinetic Modeling: Journal of Sedimentary Petrology, v.63, Nº, p.1100-1109.

BODART, D. E., 1980, Genetic models for the Precambrian Tarr albitite complex, southeastern Sinaï: geological Survey of Israël, p. 6-8.

BOLES, J. R., 1982, Active albitization of plagioclase in Gulf Coast Tertiary: American Journal of Science, v. 282, p. 165-180.

BOLES, J. R., 1984, Secondary porosity reactions in the Stevens sandstone, San Joaquin Valley, California, in McDonald, D. A., and Sirdam, R. C., eds., Clastic Diagenesis: American Association of Petroleum geologists Memoir 37, p. 217-224.

BOLES, J. R., and COOMBS, D. S., 1977. Zéolite faciès alteration of sandstones in the Southland syncline, New Zealand: American Journal of Science, v.277, p. 982-1012.

BOUDZOUMOU F., 1986. La chaîne ouest-congolienne et son avant-pays au Congo: relations avec le Mayombien; sédimentologie des séquences d'age protérozoïque supérieur. Thèse de Doctorat 3eme cycle, Université d'Aix-Marseille, 220p. 
CAHEN L., 1954. ,Géologie du Congo Belge. 580p.H.Vaillant-Carmanne, Liège.

COSSON J., 1955. Notice explicative sur les feuilles Pointe-Noire et Brazzaville. Carte géologique de reconnaissance au 1/500 000. Bull. Dir. Min. Géol., A. E. F., Brazzaville, 56 p

DADET P., 1969. Notice explicative de la carte géologique du Congo Brazzaville au $1: 500000$. Mémoire BRGM 70, 103p. G. de Bussac, Clermont-Ferrand.

DEER, W. A., HOWIE, R. A., and ZUSSMAN, J., 1963. framework silicates: Rock-forming minerals, v. 4: London, Longmans, 435p.

ESKOLA, P., VUORISTO, U., and RANKAMA, K., 1935. An experimental illustration of spilite reaction: Comptes Rendus de la Societe geologique de Finlande.

FOLK R.L., 1974. Petrology of Sédimentary rocks. Hempills, Austin, Texas.

FOX, L. K., ms, 1989, Albitisation of Jurassic plutons in the southern Bristol Mountains, east-central mojave Desert, southeastern California: Ph. D. Thesis, University of California, Santa Barbara, 324p.

FRIMMEL H. E. , TACK L., BASEI M. S., NUTMAN A.

P., BOVEN A., 2006. Provenance and chemostratigraphy of the Neoproterozoïc West congolian Group in the Democratic Republic of Congo. Journal of African Earth Sciences 46 (2006) $221-239$.

GILLULY, J., 1933. Replacement origin of the albite granite near Sparta, Oregon: U. S. Geol. Surv.Prof.Pap. 175C, p. 65-81.

GOLD, P. B., 1987. Textures and geochemistry of authigenic albite from Miocene sandstones, Louisiana Gulf Coast: Journal of Sedimentary Petrology, v.57, p.353-362.

HESS, H. H., 1950. Vertical mineral variation in the Great Dyke of Southern Rhodesia: Transactions Geological Society South Africa, v. 53, p. 159.

LAND, L. S., and MILLIKEN, K. L., 1981. Feldspar diagenesis in the Frio Formation, Brazoria County, Texas Gulf Coast: Geology, v.9, p.314318.

LAJOIE, J., 1973. Albite of secondary origin in Charny Sandstones, Quebec: a discussion: Jour. Sed. Petrology, v. 43, p. 575-577.

MOODY, J. B., JENKINS, J. E., and MEYER, D., 1985. An experimental investigation of the albitisation of plagioclase: Canadian Mineralogist, v.23, p.583-592.
MORAD, S., 1986. Albitization of K-feldspar grains in Proterozoïc arkoses and greywackes from Southern Sweden: Neues Jahrbuch für Mineralogie, 1986, p. 145-156.

MORAD, S., BERGAN, M., KNARUD, R. and NYSTUEN, J. P., 1990. Albitization of detrital plagioclase in Triassic reservoir sandstones from the Snorre field, Norwegian North Sea: Journal of Sedimentary Petrology, v.60, p.411425.

OGUNYOMI, O., MARTIN, R. F., and HESSE, R., 1981. Albite of secondary origin in Charny Sandstones, Québec: a revaluation: Journal of Sedimentary Petrology, v.51, p.597-606.

OLLERENSHAW, N. C., 1967. Région de Cuoq-Langis, Min. Richesses: Québec Dept. Nat. Resources Geol. Rept., 121, 230 p.

PEREZ Renée J.; BOLES James R., 2005. An empirically derived kinetic model for albitization of détrital plagioclase (Albitization, A Brief Review). American Journal of Science, Vol.305, April, 2005, P. 312-343.

ROSENBAUER, R. J., BISHOFF, J. L., and ZIERENBERG, R. A., 1988. The laboratory albitization of mid-ocean ridge basalt: journal of Geology, $v$. 96, p. $237-244$.

SAIGAL, G. C., MORAD, S., BJøRLYKKE, K., EGEBERG, P. K., and AAGAARD, P., 1988. Diagenetic albitization of detrital K-feldspars in Jurassic, Lower Cretaceous and Tertiary Clastic reservoir rocks from offshore Norway.l. textures and origin: Journal of sedimentary Petrology, v. 58, p. 1003-1013.

SCHMITT J. M., 1986. Albitisation triasique, hydrothermalisme jurassique et altération supergène récente: métallogénie des gisements uranifères du Rouergue. Thèse de doctorat es Sciences Naturelles, 240 p., UER des Sciences de la vie et de la Terre, Institut de Géologie, Université Louis Pasteur, Strasbourg, France.

SIMON-COINÇON R., 1989. Le rôle des paléoaltérations et des paleoformes dans les socles : l'exemple du Rouergue (Massif central français); Mémoires des sciences de la Terre $\mathrm{N}^{\circ}$ 9 (ENSMP Ecole des Mines de Paris).

SLABY, E., 1992. Changes in the structural state of secondary albite during progressive albitization: Neues Jahbruch Fuer Mineralogie, Monatshefte, v. 7, p. 321- 335 .

SMITH, J. V., 1972. Critical review of synthesis and occurrence of plagioclase feldspars and possible phase diagram: journal of Geology,v.80,p.505-525. 
SMITH, J. V., 1974. Feldspar Minerals, v.2, chemical and textural Properties: New York, pringerVerlag, $690 \mathrm{p}$.

STANTON W. I., SCHERMERHORN L. J. G. and KORPERSHOEK H. R., 1963. The West Congo System. Bol. Serv. Géol. Min., Angola, 8, 69-78.

STARKEY, J., 1959. Chessboard albite from New Brunswick, Canada:Geol. Mag., v.96, p.141145.
TAWADROS, E., 1977. Etude pétrographique des grès Cambriens du Groupe de Caldwell de la région du lac Etchemin, Québec [M.S. thesis]: Montréal, Univ. Montréal, $60 \mathrm{p}$.

TESTER, A. C., and ATWATER, G. I., 1934. the occurence of authigenic feldspar in sediments: Journal of Sedimentary Petrology, v.4, p.23-31.

WALKER, T. E., 1984. Diagenetic albitization of potassium feldspar in arkosic sandstones: 1984 SEPM Presidential Address: Journal of Sedimentary Petrology, v. 54, p. 3-16. 